\title{
Increased eNOS Accounts for Changes in Connexin Expression in Renal Arterioles During Diabetes
}

\author{
JIAN HONG ZHANG, ${ }^{1}$ SEINOSUKE KAWASHIMA, ${ }^{2}$ MITSUHIRO YOKOYAMA, ${ }^{2}$ \\ PAUL HUANG, ${ }^{3}$ AND CARYL E. HILL ${ }^{1 *}$ \\ ${ }^{1}$ Division of Neuroscience, John Curtin School of Medical Research, \\ Australian National University, Canberra, Australia \\ ${ }^{2}$ First Department of Internal Medicine, Kobe University School of Medicine, Kobe, Japan \\ ${ }^{3}$ Harvard Medical School, Cardiovascular Research Centre, \\ Massachusetts General Hospital, Charlestown, Massachusetts
}

\begin{abstract}
Previous studies have shown that connexin $(\mathrm{Cx})$ expression is considerably higher in the preglomerular compared to postglomerular vasculature and that these differences are accentuated during diabetes. Since nitric oxide (NO) has been reported to alter $\mathrm{Cx}$ expression in endothelial cells and muscle cells and NO bioavailability is altered in diabetes, we hypothesized that NO may be responsible for the changes during diabetes. Cx expression was studied using immunohistochemistry in mice in which eNOS expression was either upregulated (eNOS transgenic) or downregulated (eNOS knockout). Diabetes was induced intraperitoneally with a single dose of alloxan or multiple low doses of streptozotocin. Expression of $\mathrm{Cx} 40$ in smooth muscle cells of afferent arterioles was increased, while expression of $\mathrm{Cx} 43$ in endothelial cells of efferent arterioles was absent in eNOS transgenic mice, similar to the changes occurring in wild-type mice during diabetes. Expression of $\mathrm{Cx} 40$ and $\mathrm{Cx} 43$ in eNOS knockout mice was not different from control; however, induction of diabetes in eNOS knockout mice failed to produce any changes in $\mathrm{Cx} 40$ or $\mathrm{Cx} 43$ in either afferent or efferent arterioles. Immunohistochemistry showed that eNOS expression was increased in the endothelium of renal arterioles in wild-type diabetic and eNOS transgenic mice, but absent from arterioles of eNOS knockout mice. We conclude that changes occurring in $\mathrm{Cx}$ expression in afferent and efferent arterioles during diabetes may result from increased eNOS. Anat Rec Part A, 288A:1000-1008, 2006. @ 2006 Wiley-Liss, Inc.
\end{abstract}

Key words: eNOS; connexin; renal arterioles; diabetes

Regulation of regional blood flow and the maintenance of systemic blood pressure require integration and coordination of vascular responses within different vascular beds. The ability of arterioles to conduct vasoconstriction and vasodilation over distance along the vascular tree is critical to the local modulation of vascular resistance (Christ et al., 1996; Hill et al., 2002; Segal, 2005). This complex intrinsic integration and coordination process depends on gap junctions, which are intercellular communication channels composed of connexin molecules $(\mathrm{Cx})$ (Hill et al., 2001). In studies of many different arteries
Grant sponsor: The National Heart Foundation; Grant number: Grant-in-Aid G03C 1059.

*Correspondence to: Caryl E. Hill, Division of Neuroscience, John Curtin School of Medical Research, Australian National University, Canberra, ACT 2602, Australia. Fax: 61-2-6125-8077.

E-mail: caryl.hill@anu.edu.au

Received 14 May 2006; Accepted 9 June 2006

DOI 10.1002/ar.a.20369

Published online 4 August 2006 in Wiley InterScience (www.interscience.wiley.com). 
and arterioles, Cxs37, 40, and 43 have been readily detected between adjacent endothelial cells, while $\mathrm{Cx}$ expression is more limited among smooth muscle cells, particularly in resistance arteries and arterioles and the specific subtype debatable (Hill et al., 2001, 2002).

A number of factors have been described to modulate $\mathrm{Cx}$ expression, conductance, and permeability of gap junctions to cytosolic molecules (Harris, 2001). In vitro studies have shown that exogenous nitric oxide (NO) increased the expression of $\mathrm{Cx} 40$ in endothelial gap junctions (Hoffmann et al., 2003) and Cx43 expression in mesangial cells (Yao et al., 2005) but decreased Cx43 expression in uterine myocytes (Sladek et al., 1999; Roh et al., 2002). Elevated glucose has also been shown to inhibit gap junctional communication in cultured smooth muscle cells through alterations to the phosphorylation of Cx43 (Kuroki et al., 1998) and in cultured microvascular endothelial cells through downregulation of $\mathrm{Cx} 43$ expression (Sato et al., 2002).

In our previous experiments, we demonstrated extensive expression of Cxs37, 40, and 43 in endothelial cells and Cx37 in smooth muscle cells of the preglomerular renal vasculature but only $\mathrm{Cx} 43$ in endothelial cells of the postglomerular vasculature (Zhang and Hill, 2005). Cxs37 and 40 were expressed strongly in the reninsecreting cells. During diabetes, expression of $\mathrm{Cx} 40$ was increased in smooth muscle cells of the afferent arterioles while $\mathrm{Cx} 43$ was decreased in endothelial cells of the efferent arterioles (Zhang and Hill, 2005). Since previous studies have shown that the bioavailability of NO is altered during diabetes (Prabhakar, 2004; Schalkwijk and Stehouwer, 2005), the aim of the present study was to determine whether changes in endothelial NO were responsible for the changes in $\mathrm{Cx}$ expression observed in the juxtaglomerular apparatus. For these studies, we used genetically modified mice in which endothelial nitric oxide synthase (eNOS) expression was either upregulated (eNOS transgenic) or downregulated (eNOS knockout). To test the involvement of eNOS in $\mathrm{Cx}$ changes during diabetes, we induced diabetes in eNOS gene-modified mice using streptozotocin or alloxan.

\section{MATERIALS AND METHODS}

Experiments were performed under a protocol approved by the Animal Experimentation Ethics Committee of the Australian National University. All procedures were conducted in accordance with the Australian Code of Practice for the Care and Use of Animals for Scientific Purposes. Mice were housed under 12-hr light/dark cycles and given food and water ad libitum.

\section{Animals}

In eNOS transgenic mice, overexpression of the bovine eNOS gene in endothelial cells of the vascular wall (Ohashi et al., 1998) was achieved through the use of the murine preproendothelin-1 promoter (Harats et al., 1995). Characterization of this mouse has been published previously (Ohashi et al., 1998; Yamashita et al., 2000; Kawashima et al., 2001; Ozaki et al., 2002); eNOS transgenic mice were hypotensive (Ohashi et al., 1998). eNOS knockout mice were created by targeted disruption of the eNOS gene and confirmed by Southern and Western blot analysis. These mice developed hypertension (Huang et al., 1995).
Heterozygous eNOS transgenic mice were backcrossed to wild-type C57BL/6 for at least seven generations while eNOS knockout mice were inbred. Ageand sex-matched wild-type C57BL/6 mice were used as control (Huang et al., 1995), in addition to the negative littermates of transgenic matings, as preliminary experiments did not demonstrate any differences between these groups. Identification of eNOS transgenic founder mice and offspring was done by PCR genotyping. Primers were 5'-GGTCTTATCTCTGGCTGCACGTT-3' (sense, located in the preproendothelin-1 promoter) and 5'-CACAGAGTGTCGTAGGTGATGCT- $3^{\prime}$ (antisense, located in the eNOS gene), giving a product of $582 \mathrm{bp}$. PCR conditions were $95^{\circ} \mathrm{C}$ for $15 \mathrm{sec}, 65^{\circ} \mathrm{C}$ for $15 \mathrm{sec}, 72^{\circ} \mathrm{C}$ for $60 \mathrm{sec} ; 35$ cycles. The published eNOS transgenic sequence (Ohashi et al., 1998) was confirmed by DNA cloning and sequencing of the PCR product.

\section{Diabetes Protocol}

Diabetes was induced in male eNOS transgenic mice, their negative littermates, and eNOS knockout mice (8-10 weeks) by intraperitoneal injection of either a single-dose alloxan (5,6-dioxyuracil monohydrate; $175 \mathrm{mg} /$ $\mathrm{kg}$ body weight; Sigma-Aldrich, St. Louis, MO) in normal saline or multiple low doses of streptozotocin [2-deoxy(3methyl-3-nitrosoureido)-D-glucopyranose; $40 \mathrm{mg} / \mathrm{kg}$ body weight; Calbiochem, Darmstadt, Germany] in 0.2 M acetate-buffered saline ( $\mathrm{pH} 4.4)$ on 5 consecutive days. The former method produces a rapid rise in blood glucose and drug-induced death of pancreatic $\beta$-cells (Szkudelski, 2001 ), while the latter approximates more closely human diabetes with a slower death of $\beta$-cells due to insulitis (Paik et al., 1980). Both methods were used to induce diabetes in all three groups of mice.

Capillary blood glucose level was determined using Medisense blood glucose electrode sensor (Abbott Laboratories, Victoria, Australia). Diabetes was defined as a nonfasting capillary blood glucose level $\geq 15 \mathrm{mM}$. Vehicle-injected mice were used as control. Blood glucose levels and body weight were monitored twice a week. Intraperitoneal supplement of saline was given to mice whose body weight loss was more than $1 \mathrm{~g} /$ day. This only applied to the mice treated with a single dose of alloxan and occurred in the first and occasionally in the second week following injection.

Our preliminary studies showed that the changes in $\mathrm{Cx}$ expression in diabetes induced with a single-dose alloxan in wild-type C57BL/6 mice were maximal after 8 to 10 weeks of established diabetes, as we had previously found for high doses of streptozotocin (Zhang and Hill, 2005). Our preliminary data with mice in which diabetes was induced with multiple low doses of streptozotocin showed that similar $\mathrm{Cx}$ changes occurred but these were not maximal until 14 to 16 weeks of established diabetes. These times formed the endpoints for our studies. It should be noted, however, that the duration of diabetes was similar for the two methods since diabetes was induced rapidly in the case of alloxan, i.e., by day 3 postinjection, but slowly in the case of multiple low doses of streptozotocin, i.e., 30 to 40 days postinjection. Consequently, the duration of diabetes for both methods was $8-10$ weeks. 


\section{Immunohistochemistry}

Male wild-type, eNOS transgenic, and eNOS knockout mice and their diabetic counterparts $(n=4$, minimum for each group) were deeply anesthetized ( $5 \mathrm{mg} / \mathrm{kg}$ xylazine and $25 \mathrm{mg} / \mathrm{kg}$ ketamine, i.p.). Fresh renal blocks were fixed in acetone $\left(4^{\circ} \mathrm{C}\right.$ for $\left.30 \mathrm{~min}\right)$, thoroughly washed with phosphate-buffered saline (PBS), immersed in $30 \%$ sucrose in PBS $\left(4^{\circ} \mathrm{C}\right.$ overnight), and embedded in Cryo-M-Bed (Bright Instrument, Cambridge, U.K.). Coronal sections were cut at $30 \mu \mathrm{m}$, mounted onto $2 \%$ silane (Sigma-Aldrich, Sydney, Australia)-coated slides, dried, and stored frozen.

Frozen tissue sections were preincubated in $2 \%$ BSA and $0.2 \%$ Triton in PBS and then in sheep antibodies against rat Cxs37, 40 (1:250) (Rummery et al., 2002), or rabbit antibody against rat $\mathrm{Cx} 43$ (1:250; Zymed Laboratories, San Francisco, CA) in the same solution for $48 \mathrm{hr}$ at room temperature. The specificity of these three antibodies has been confirmed previously by Western blotting and immunohistochemistry of COS-7 cells transfected with plasmid DNA encoding either Cxs37, 40, or 43 (Rummery et al., 2005). Specific Cx subtype staining was detected using either Cy3-conjugated antigoat IgG (1:600; Jackson ImmunoResearch Laboratories, West Grove, PA) or Alexa Fluor 568-conjugated antirabbit IgG (1:600; Molecular Probes, Eugene, OR) in $0.2 \%$ Triton in PBS for $2 \mathrm{hr}$.

For assessment of eNOS protein expression, fresh renal blocks were immersion-fixed in $2 \%$ paraformaldehyde in $0.1 \mathrm{M}$ sodium phosphate buffer ( $\mathrm{pH}$ 7.4) for $10 \mathrm{~min}$ at room temperature. For assessment of iNOS protein expression, renal blocks were fixed in cold acetone for 30 min. In both cases, tissue blocks were further processed as indicated above.

Expression of eNOS and iNOS protein was determined with rabbit polyclonal anti-eNOS (1:100; Abcam, Cambridge, U.K.) and anti-iNOS (1:1,000; Zymed Laboratories, South San Francisco, CA), subsequently detected with Alexa Fluor 568-conjugated antirabbit IgG (1:600). The specificity of eNOS and iNOS antibodies was tested on renal tissues from eNOS knockout and iNOS knockout mice, respectively. Identification of vascular smooth muscle cells was achieved by subsequent labeling with rabbit antimyosin (U. Gröschel-Stewart, Technische Universitat, Darmstadt, Germany; 1:250) detected by FITCconjugated antirabbit IgG (Dako, Denmark, 1:40).

\section{Collection and Analysis of Data}

Images were obtained using a confocal laser scanning microscope and Argon/Kryton laser (TCS 4D; Leica Instruments, Vienna, Austria). Serial images at $1 \mu \mathrm{m}$ intervals were obtained in the Z-axis, encompassing entire blood vessels and recombined. For dual-labeled sections, either composite or individual images were combined in Adobe Photoshop as indicated. For comparisons using the same antibody in tissues from different animals, images were obtained at the same pinhole, laser intensity, and voltage settings. For each animal, at least four pictures from four different visual fields were taken and for each group four different animals were included. In order to assess the extent of nonspecific staining, the primary antibody was preincubated with the appropriate antigenic peptide before being applied to tissue sections or the primary antibody was omitted. Alternatively, solutions containing the primary antibody were applied to tissue sections from the relevant gene knockout mice, for example, anti-eNOS applied to tissues from eNOS knockout mice.

Semiquantification of $\mathrm{Cx}$ staining was undertaken on confocal images of afferent arterioles (Cxs37, 40) and efferent arterioles (Cx43). Assessment of the amount of staining among the control and diabetic mice groups was made blindly by two people (one of the two authors and another independent person) using unlabeled micrographs representing afferent or efferent arterioles from a minimum of four different animals in each group. This method allowed differentiation of $\mathrm{Cx}$ staining between smooth muscle cells and endothelial cells in afferent arterioles, which was not possible using the computerbased software program in our previous studies (Zhang and Hill, 2005).

The level of Cx37 expression in smooth muscle cells of afferent arterioles was assessed from + to +++ , representing, respectively, no $\mathrm{Cx}$ staining beyond renin-secreting cells; weak and irregular $\mathrm{Cx}$ staining; strong, uniform $\mathrm{Cx}$ staining.

$\mathrm{Cx} 43$ expression in endothelial cells of efferent arterioles was categorized from + to +++ , representing, respectively, no Cx staining; Cx staining in efferent arterioles but less than in afferent arterioles; $\mathrm{Cx}$ staining in efferent arterioles equivalent to that in afferent arterioles.

Cx40 expression in smooth muscle cells of afferent arterioles was categorized from + to ++++ , representing, respectively, no $\mathrm{Cx}$ staining beyond renin-secreting cells; staining in muscle cells immediately adjacent to reninsecreting cells (usually within $40 \mu \mathrm{m}$ ); weak staining in muscle cells located beyond $40 \mu \mathrm{m}$ from renin-secreting cells; strong staining in distal smooth muscle cells.

For statistical analysis, the semiquantitative variables $(+$ to ++++$)$ were assigned a value from 1.0 to 4.0. Data were expressed as mean \pm SEM and analyzed using one-way ANOVA and nonpaired $t$-test with Bonferroni correction for multiple comparisons. Statistical significance was set at $P<0.05$.

\section{RESULTS}

All the diabetic mice injected with multiple low doses of streptozotocin survived to the endpoint of the experiments and the body weight of diabetic mice was not significantly different to that of control mice (wild-type control, $26.9 \pm 1.08 \mathrm{~g}$; wild-type diabetic, $24.6 \pm 0.65 \mathrm{~g}$; eNOS transgenic control, $24.7 \pm 0.84 \mathrm{~g}$; transgenic diabetic, $24.2 \pm 0.65 \mathrm{~g}$; eNOS knockout control, $27.2 \pm 2.19$ g; knockout diabetic, $26.1 \pm 1.54 \mathrm{~g}$ ). In the case of diabetes induction with a single dose of alloxan, $20 \%$ of the wild-type and eNOS knockout mice and all of the eNOS transgenic mice died before the endpoint of the experiment. Body weights of surviving diabetic mice were not significantly different to those of control mice (wild-type control, $25.3 \pm 0.83 \mathrm{~g}$; wild-type diabetic, $23.9 \pm 0.16 \mathrm{~g}$; eNOS transgenic control, $24.7 \pm 0.87 \mathrm{~g}$; eNOS knockout control, $26.2 \pm 0.76 \mathrm{~g}$; knockout diabetic, $23.0 \pm 1.96 \mathrm{~g}$ ).

Renal arterioles were identified with antimyosin staining. Afferent arterioles were distinguished from efferent arterioles by their larger diameter in the superficial cortex, absence of branching prior to entering the glomerulus, direct communication with larger interlobular 

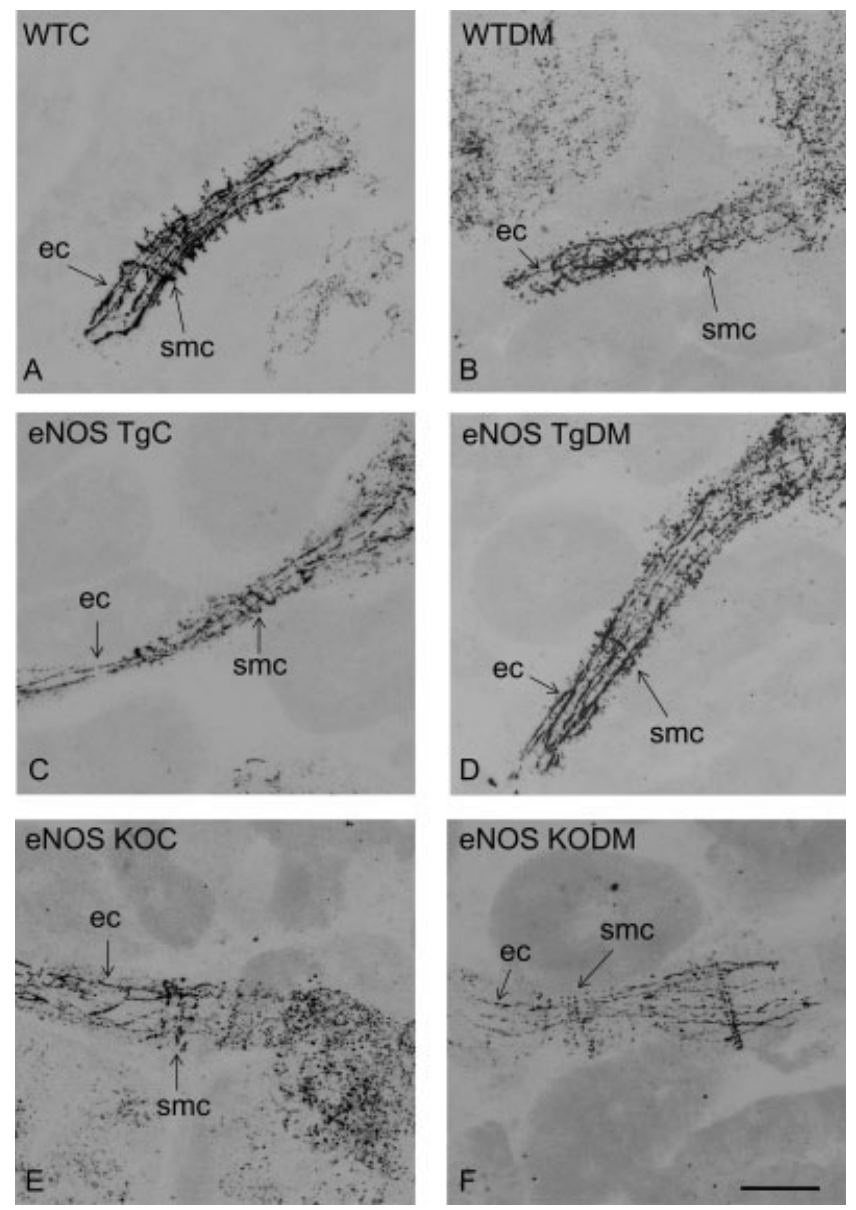

Fig. 1. Expression of Cx37 in afferent arterioles. Cx37 was found in longitudinally aligned endothelial cells (ec) and transversely aligned smooth muscle cells (smc) of afferent arterioles from wild-type (WTC, A), eNOS transgenic control (eNOS TgC; C), eNOS knockout control mice (eNOS KOC, E), and their corresponding diabetic mice (WTDM, B; eNOS TgDM, D; eNOS KODM, F). The vessels are oriented longitudinally from left to right. Scale bar $=20 \mu \mathrm{m}$.

arteries (Harrison-Bernard et al., 2006), and regular, uniform antimyosin staining of smooth muscle cells. In contrast, antimyosin staining in smooth muscle cells of efferent arterioles was irregular and heterogeneous, in part due to the irregular alignment of smooth muscle cells (Evan and Dail, 1977; Gattone et al., 1984; Bankir et al., 1987; Yuan et al., 1990: e.g., Fig. 4A-F). Reninsecreting cells were identified by their anatomical position immediately adjacent to the vascular pole of the glomerulus (Zaki et al., 1982). Extraglomerular mesangial cells were identified by their location in the triangle surrounded by the afferent arteriole, the efferent arteriole, and the distal tubule.

Double labeling with $\mathrm{Cx}$ and myosin antibodies confirmed that $\mathrm{Cx}$ staining oriented along the vessel axis was associated with the endothelium while that at right angles to the vessel axis lay between smooth muscle cells as we have demonstrated previously (Zhang and Hill, 2005). For all Cx antibodies, there was no Cx staining when the primary antibody was omitted or when the
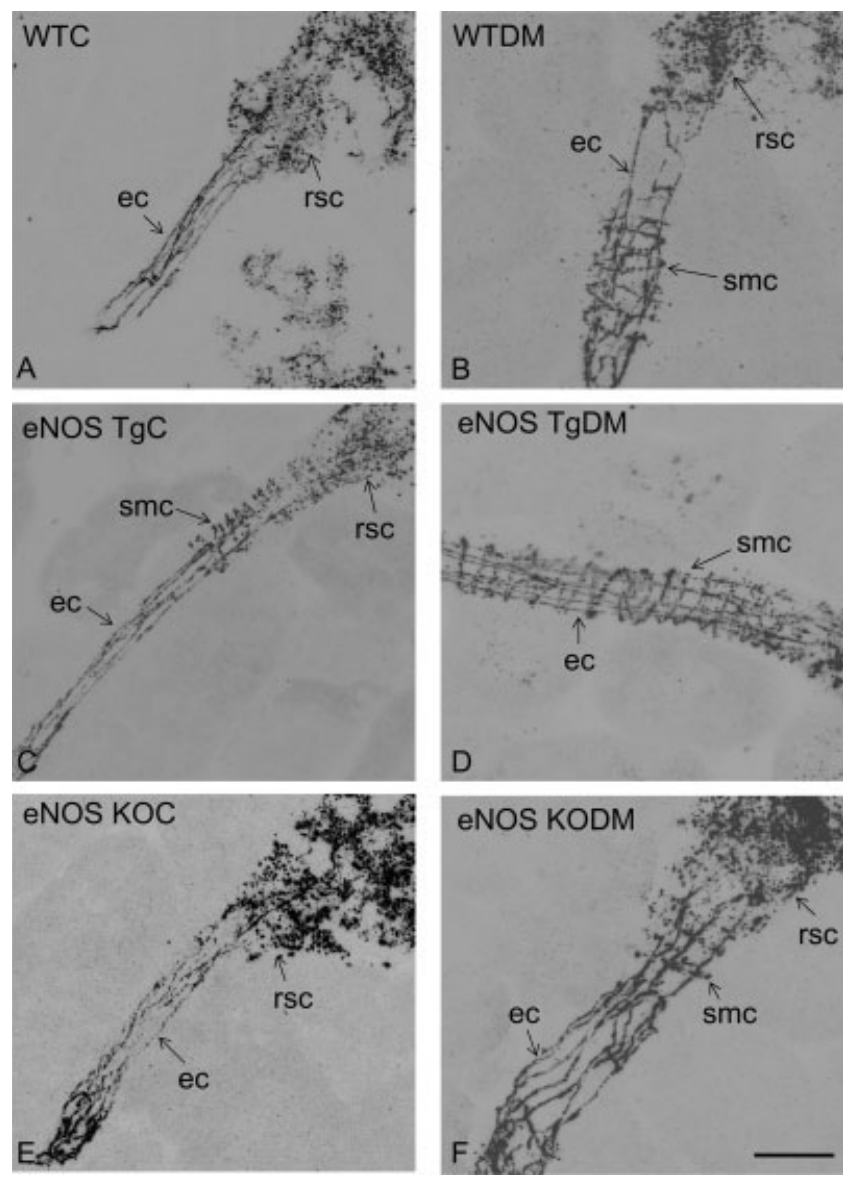

Fig. 2. Expression of $\mathrm{Cx} 40$ in afferent arterioles. $\mathrm{C} \times 40$ was detected in endothelial cells (ec), renin-secreting cells (rsc), and the immediately adjacent smooth muscle cells (smc) from wild-type control (WTC, A), eNOS transgenic (eNOS TgC, C), eNOS knockout control (eNOS KOC, E), and eNOS knockout diabetic mice (eNOS KODM, F). An increased expression of $\mathrm{Cx} 40$ in the more distal smooth muscle cells was detected in diabetic mice from wild-type (WTDM, B) and eNOS transgenic (eNOS TgDM, D) but not in eNOS KO mice. The longitudinal axis of the vessels runs from left to right. Scale bar $=20 \mu \mathrm{m}$.

primary antibody was preincubated with the corresponding antigenic peptide. No differences were noted in the immunohistochemical results between the two methods to induce diabetes.

\section{Connexin Expression in Afferent Arterioles}

Nondiabetic mice. $\mathrm{Cx} 37$ and $\mathrm{Cx} 40$ were consistently detected in endothelial cells and renin-secreting cells of afferent arterioles from wild-type, eNOS transgenic, and eNOS knockout mice (Figs. 1A, C, and E and 2A, C, and E).

In wild-type and eNOS transgenic mice, expression of Cx37 was more regular and consistent in smooth muscle cells of the afferent arterioles (Fig. 1A and C) compared to that in eNOS knockout mice (Fig. 1E). However, no statistically significant difference was detected among the three mice groups, although there was a tendency for reduced expression in the eNOS knockout mice (Table 1, control). 
TABLE 1. Semi-quantification of Cx37 expression in afferent arterioles

\begin{tabular}{lcc}
\hline & Control & Diabetes \\
\hline WT & $2.0 \pm 0.45(5)$ & $1.8 \pm 0.31(6)$ \\
eNOS Tg & $2.2 \pm 0.31(6)$ & $2.5 \pm 0.50(4)$ \\
eNOS KO & $1.5 \pm 0.22(6)$ & $1.3 \pm 0.21(6)$ \\
\hline
\end{tabular}

No significant differences amongst wild type (WT), eNOS transgenic (Tg) and eNOS knockout (KO) mice and their diabetic counterparts $(\mathrm{p}>0.05)$. The numbers in parentheses represent the number of animals studied.

TABLE 2. Semi-quantification of Cx40 expression in afferent arterioles

\begin{tabular}{lcc}
\hline & Control & Diabetes \\
\hline WT & $1.6 \pm 0.40(5)$ & $3.0 \pm 0.32(5)^{*}$ \\
eNOS Tg & $2.3 \pm 0.25(4)^{\#}$ & $4.0 \pm 0.00(4)^{\dagger}$ \\
eNOS KO & $1.0 \pm 0.00(4)$ & $1.5 \pm 0.50(4)$ \\
\hline
\end{tabular}

${ }^{\# p}<0.05$ compared to eNOS knockout control mice; $* \mathrm{p}<$ 0.05 compared to wild type control mice.

${ }^{\dagger} \mathrm{p}<0.05$ compared to eNOS Tg control mice. Numbers in parentheses represent the number of animals studied. KO: knockout. WT: wild type, Tg: transgenic; KO: knockout.

In wild-type mice, expression of $\mathrm{Cx} 40$ was more restricted to the smooth muscle cells immediately adjacent to the renin-secreting cells (Fig. 2A), while in the corresponding areas in eNOS knockout mice, Cx40 was either similar to or weaker than that in the wild-type mice (Fig. $2 \mathrm{E}$ ). In contrast, clear and consistent $\mathrm{Cx} 40$ staining in the smooth muscle cells beyond the renin-secreting cells was detected in eNOS transgenic mice (Fig. 2C). Semiquantification of $\mathrm{Cx} 40$ staining showed a significant increase in $\mathrm{Cx}$ expression in the afferent arterioles of eNOS transgenic mice compared to that in eNOS knockout mice $(P<$ 0.05; Table 2, control). No significant difference in $\mathrm{Cx}$ staining was observed between wild-type and eNOS transgenic mice or wild-type and eNOS knockout mice.

$\mathrm{Cx} 43$ was detected in endothelial cells of afferent arterioles from wild-type, eNOS transgenic, and eNOS knockout mice (Fig. 3A, C, and E). Cx43 was not detected in smooth muscle cells of afferent arterioles in any of the three groups.

Diabetic mice. Since the previous sections indicated that overexpression of eNOS mimicked changes of Cxs seen previously in diabetes (Zhang and Hill, 2005), we tested this hypothesis by inducing diabetes in eNOS knockout mice.

Expression of Cx37 and Cx40 in endothelial cells and renin-secreting cells of afferent arterioles was similar among wild-type, eNOS transgenic, and eNOS knockout diabetic mice (Figs. $1 \mathrm{~B}, \mathrm{D}$, and $\mathrm{F}$ and $2 \mathrm{~B}, \mathrm{D}$, and $\mathrm{F}$ ).

In the smooth muscle cells, expression of $\mathrm{Cx} 37$ was also similar among wild-type, eNOS transgenic, and eNOS knockout diabetic mice (Fig. 1B, D, and F). No statistically significant difference was detected between control mice and their counterpart diabetic mice, although there was a tendency for reduced expression in eNOS knockout mice $(P>0.05$; Table 1$)$.
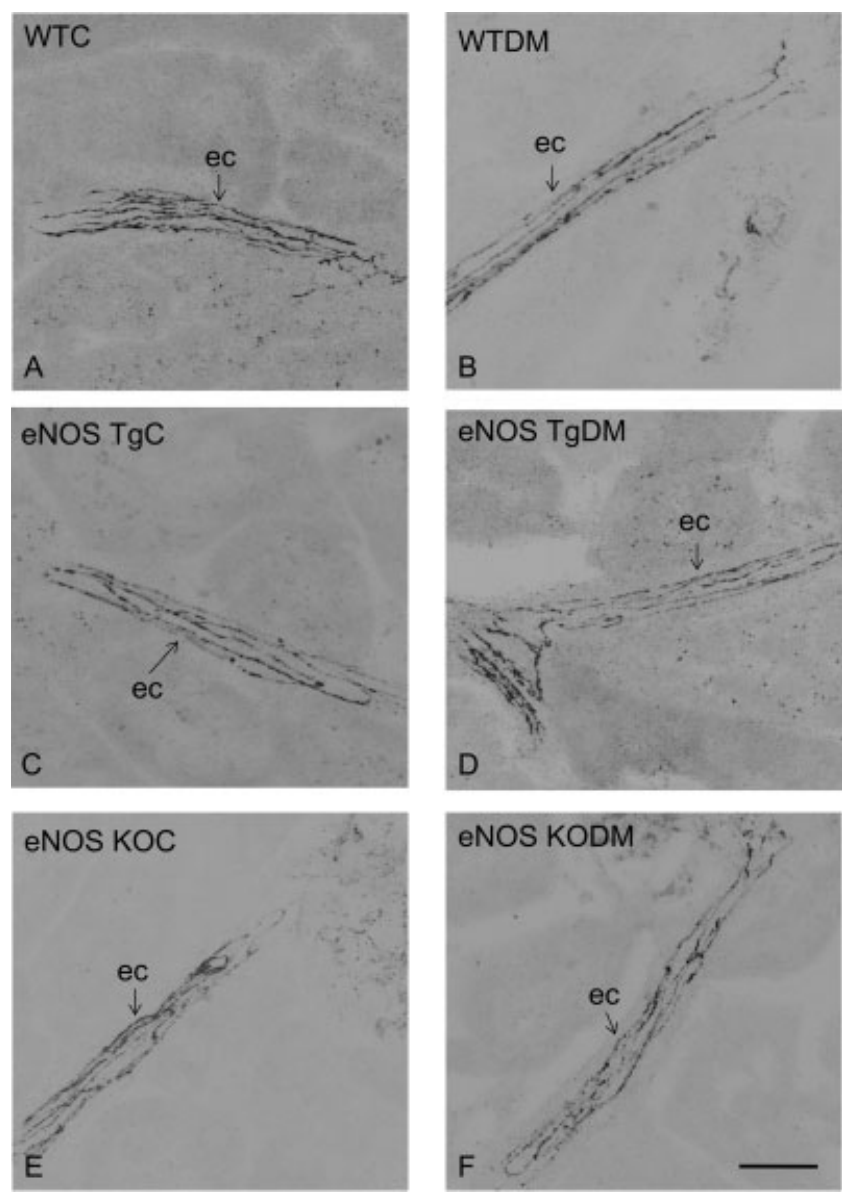

Fig. 3. Expression of $\mathrm{Cx} 43$ in afferent arterioles. Cx43 was detected in endothelial cells (ec) in wild-type control (WTC, A) and diabetic mice (WTDM, B), eNOS transgenic control (eNOS TgC, C) and diabetic mice (eNOS TgDM, D), eNOS knockout control (eNOS KOC, E), and diabetic mice (eNOS KODM, F). No staining was detected in the smooth muscle cells. The vessels were oriented longitudinally from left to right. Scale bar $=20 \mu \mathrm{m}$.

Expression of $\mathrm{Cx} 40$ was increased in the distal smooth muscle cells of afferent arterioles of both wild-type diabetic mice and eNOS transgenic diabetic mice, the staining being more consistent in eNOS transgenic mice than that in wild-type mice (Fig. 2A-D). In eNOS knockout diabetic mice, $\mathrm{Cx} 40$ staining was restricted to the smooth muscle cells immediately adjacent renin-secreting cells (Fig. 2F). Semiquantification of $\mathrm{Cx} 40$ in smooth muscle cells showed a significant increase in $\mathrm{Cx}$ staining in wild-type diabetic mice compared to wild-type control and in eNOS transgenic diabetic mice compared to eNOS transgenic control mice $(P<0.05$; Table 2$)$. No significant difference was detected in $\mathrm{Cx}$ staining between eNOS knockout diabetic mice and eNOS knockout control mice $(P>0.05$; Table 2$)$. However, expression of $\mathrm{Cx} 40$ in afferent arterioles of eNOS knockout diabetic mice was significantly less than that in afferent arterioles of wild-type diabetic or eNOS transgenic diabetic mice $(P<0.05)$.

Cx43 was detected in endothelial cells of afferent arterioles from all diabetic groups in a similar manner to 

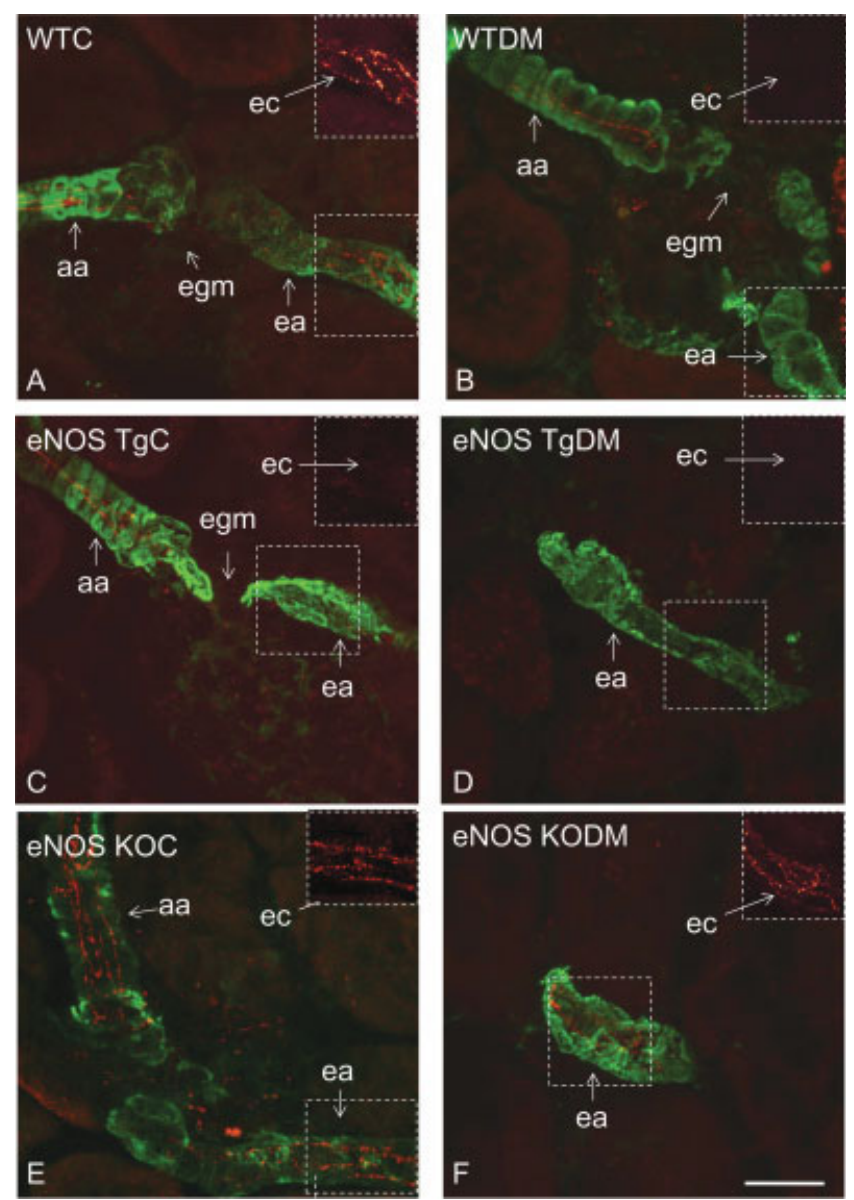

Fig. 4. Expression of Cx43 in efferent arterioles. When arterioles were labeled with antimyosin staining, Cx43 was detected in endothelial cells (ec) of the efferent arterioles (ea) in wild-type (WTC, A) and eNOS knockout control mice (eNOS KOC, E), but it was not detected in eNOS transgenic control mice (eNOS TgC, C). In diabetes, Cx43 staining was reduced in wild-type diabetic (WTDM, B), while it was unchanged in eNOS knockout diabetic mice (eNOS KODM, F). Cx43 was not detected in eNOS transgenic diabetic mice (eNOS TgDM, D). Cx43 was not detected in extraglomerular mesangial cells (egm) in all groups. The insets show Cx43 staining in the same field as the box but without double labeling with antimyosin. Afferent arterioles (aa) were oriented on the left (A, B, C, E). Scale bar $=20 \mu \mathrm{m}$.

that in the control groups (Fig. 3). Cx43 was not detected in the smooth muscle cells of any diabetic mice (Fig. 3B, D, and F).

\section{Connexin Expression in Efferent Arterioles}

Nondiabetic mice. Only $\mathrm{Cx} 43$ was detected in endothelial cells of efferent arterioles from wild-type mice (Fig. 4A), as we have reported previously (Zhang and Hill, 2005). In contrast, $\mathrm{Cx} 43$ was not found in endothelial cells of efferent arterioles in eNOS transgenic mice (Fig. 4C) but was detected strongly in endothelial cells of efferent arterioles in eNOS knockout mice (Fig. 4E). Semiquantification of $\mathrm{Cx}$ staining showed a significant decrease in $\mathrm{Cx}$ expression in endothelial cells of efferent arterioles in eNOS transgenic mice compared to that in
TABLE 3. Semi-quantification of $\mathrm{Cx} 43$ in efferent arterioles

\begin{tabular}{llc}
\hline & \multicolumn{1}{c}{ Control } & Diabetes \\
\hline WT & $2.2 \pm 0.20(5)$ & $1.4 \pm 0.25(5)^{*}$ \\
eNOS Tg & $1.0 \pm 0.00(4)^{\dagger}$ & $1.0 \pm 0.00(4)$ \\
eNOS KO & $2.8 \pm 0.25(4)$ & $2.8 \pm 0.25(4)$ \\
\hline
\end{tabular}

${ }^{\dagger} \mathrm{p}<0.05$ compared to wild type (WT) control and eNOS knockout (KO) control mice.

$* p<0.05$ compared to wild type control mice. The numbers in the parentheses represent the number of animals studied. Tg: transgenic.

wild-type control mice or in eNOS knockout control mice $(P<0.05$; Table 3, control). However, no difference was detected between wild-type control and eNOS knockout control mice $(P>0.05$; Table 3, control). Neither Cxs37, 40 (not shown), nor $\mathrm{Cx} 43$ was detected in the smooth muscle cells of efferent arterioles in any of the three groups (Fig. 4A, C, and E).

Diabetic mice. During diabetes, Cxs37 and 40 remained absent from endothelial cells of efferent arterioles in wild-type, eNOS transgenic, and knockout mice. Expression of Cx43 in endothelial cells of efferent arterioles was reduced in wild-type diabetic mice compared to that in wild-type control mice (Fig. $4 \mathrm{~A}$ and B). No $\mathrm{Cx} 43$ was detected in eNOS transgenic diabetic mice (Fig. 4D), while Cx43 was readily detected in endothelial cells of efferent arterioles in eNOS knockout diabetic mice (Fig. 4F). Semiquantification of $\mathrm{Cx}$ staining showed a significant decrease in $\mathrm{Cx} 43$ in wild-type diabetic mice compared to that in wild-type control mice $(P<0.05$; Table 3), consistent with our previous results (Zhang and Hill, 2005). No significant difference was detected between eNOS transgenic control and diabetic mice or between eNOS knockout control and diabetic mice $(P>$ 0.05; Table 3). Expression of $\mathrm{Cx} 43$ was significantly greater in efferent arterioles of eNOS knockout diabetic mice than in efferent arterioles of wild-type diabetic or eNOS transgenic diabetic mice $(P<0.05)$. No Cxs were detected in the smooth muscle cells of efferent arterioles in any of the diabetic groups.

\section{Expression of eNOS Protein in Normal and Diabetic Mice}

eNOS was expressed in endothelial cells of large and small arteries in wild-type mice (Fig. 5A). In eNOS transgenic mice, staining for eNOS was markedly stronger but still confined to the endothelium of the vascular wall (Fig. 5B). eNOS expression was absent from the endothelium of the vascular wall in eNOS knockout mice (Fig. 5C).

During diabetes, the intensity of eNOS fluorescence in the endothelium of afferent arterioles was markedly increased in wild-type diabetic mice (Fig. 5D) compared to that in wild-type control mice (Fig. 5A). eNOS expression in eNOS transgenic diabetic mice (Fig. 5E) was similar to or weaker than that in eNOS transgenic control mice (Fig. 5B). eNOS expression was absent from the endothelium of the eNOS knockout diabetic mice. 

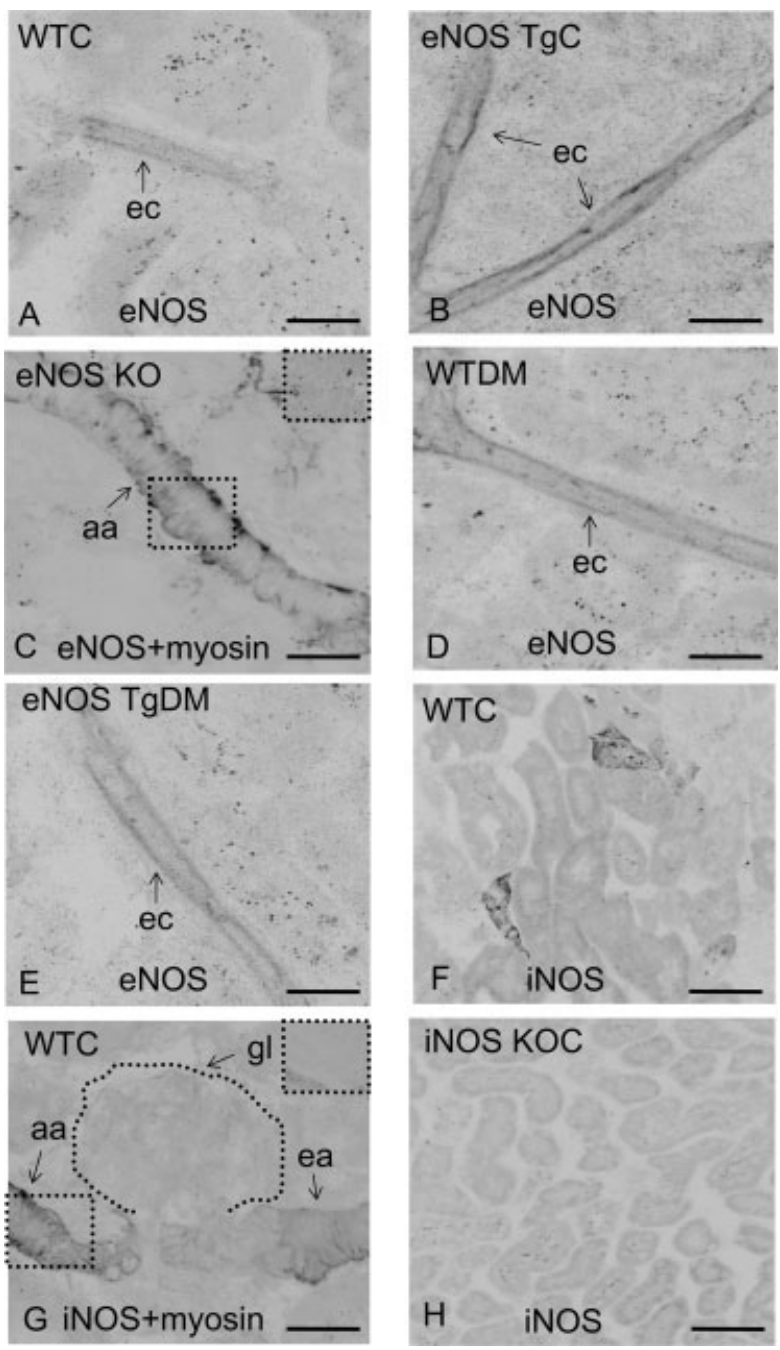

Fig. 5. Expression of eNOS and iNOS protein. eNOS was detected in endothelial cells of afferent arterioles (aa) in wild-type control (WTC, A) and diabetic mice (WTDM, D), eNOS transgenic control (eNOS $\mathrm{TgC}, \mathrm{B})$ and diabetic mice (eNOS TgDM, E). eNOS protein was not detected in eNOS knockout control mice when double-labeled with antimyosin staining (eNOS KOC, C). iNOS expression was not detected in smooth muscle cells of afferent arterioles (aa) or efferent arterioles (ea) in wild-type control mice when double-labeled with antimyosin staining (WTC, G), nor was iNOS detected inside the glomerulus (WTC, G). iNOS protein was detected in renal tubules in wild-type control mice (WTC, F) but not in iNOS knockout mice (iNOS KOC, H). The insets showed anti-eNOS (C) or anti-iNOS (G) staining in the same field as the box but without double labeling with antimyosin. $\mathrm{gl}$, glomerulus. Scale bars $=20 \mu \mathrm{m}$ in A-D, E and G; $50 \mu \mathrm{m}$ in F and $\mathrm{H}$.

\section{Expression of iNOS Protein in Juxtaglomerular Apparatus}

iNOS protein expression was mainly detected in the tubules located in the medulla and occasionally in some tubules in the cortex of wild-type and eNOS transgenic mice (Fig. 5F). iNOS protein was not expressed in the afferent or efferent arterioles when double-labeled with antimyosin staining (Fig. 5G) in any of the mice groups under normal or diabetic conditions. The specificity of iNOS anti- body was confirmed by lack of iNOS staining in tubules within the renal medulla of iNOS knockout mice (Fig. 5H).

\section{DISCUSSION}

Our study has shown that in eNOS transgenic mice, $\mathrm{Cx} 40$ was well expressed in smooth muscle cells of afferent arterioles, while $\mathrm{Cx} 43$ was absent from endothelial cells of efferent arterioles. This pattern is similar to that observed in wild-type mice during diabetes (Zhang and Hill, 2005). In contrast, expression levels of Cxs40 and 43 in afferent and efferent arterioles of eNOS knockout mice were similar to those of wild-type mice. Furthermore, induction of diabetes in eNOS knockout mice failed to produce any changes in $\mathrm{Cx}$ expression in either afferent or efferent arterioles, suggesting that changes in $\mathrm{Cx}$ expression associated with diabetes correlate with an increase in eNOS expression. Immunohistochemistry confirmed that eNOS was upregulated in endothelial cells of wild-type mice during diabetes and in eNOS transgenic mice but was absent from eNOS knockout mice. The effect on $\mathrm{Cx}$ expression was not due to compensatory changes in iNOS since expression of iNOS was not detected in either afferent arterioles or efferent arterioles in any of the mice groups.

Our data suggest that overexpression of eNOS during diabetes produces completely different changes in Cxs in afferent and efferent arterioles. This differential responsiveness is consistent with numerous studies that have shown differences in structure and function of these two arterioles. Thus, the vascular wall of afferent arterioles is thick and composed of uniformly distributed smooth muscle cells, while the vascular wall of efferent arterioles in the superficial cortex is thin, irregular, and composed of irregularly shaped smooth muscle cells (Evan and Dail, 1977; Gattone et al., 1984; Bankir et al., 1987; Yuan et al., 1990). This morphological heterogeneity of renal arterioles was confirmed by antimyosin staining in the present study and was one of the criteria used to differentiate afferent arterioles from efferent arterioles. Furthermore, myosin heavy chain-B isoform is predominantly expressed in afferent arterioles, whereas myosin heavy chain-A isoform is only expressed in the efferent arterioles (Shiraishi et al., 2003). From a functional standpoint, differences also exist. Thus, afferent arterioles express both angiotensin type $1 \mathrm{~A}$ and type $1 \mathrm{~B}$ receptors while efferent arterioles exclusively express type $1 \mathrm{~A}$ receptors (Harrison-Bernard et al., 2006). Furthermore, contractile responses in afferent arterioles are more dominated by voltage-dependent ion channels than those of efferent arterioles (Carmines and Navar, 1989; Loutzenhiser and Loutzenhiser, 2000; Hansen et al., 2001). Differential remodeling of afferent and efferent arterioles during diabetes has also been reported in streptozotocin-treated diabetic rats (Turoni et al., 2005).

The nature of the changes in $\mathrm{Cx}$ expression in afferent versus efferent arterioles suggests that eNOS overexpression accentuates the limited coupling between preglomerular vasculature and postglomerular vasculature. This accentuation might further aggravate glomerular hyperfiltration in the early stage of diabetes (Carmines and Fujiwara, 2002). Increased Cx expression within the preglomerular smooth muscle might also enhance the differential neural control of afferent and efferent arterioles, leading to increased pressure drop across the glo- 
merulus (Denton et al., 2004), further precipitating glomerular hyperfiltration.

Increased expression of eNOS has been shown previously in the aorta (Asaba et al., 2005) and glomeruli of diabetic rats (Satoh et al., 2005). However, the increased eNOS expression in the latter study was accounted for by monomeric eNOS, rather than the functional dimeric eNOS, which was decreased. Thus, these changes in eNOS resulted in reduced generation of NO (Satoh et al., 2005) and increased production of reactive oxygen species (ROS) due to eNOS uncoupling (Satoh et al., 2005; Bevers et al., 2006). Since ROS and high glucose are also NO scavengers, the bioavailability of NO during diabetes is further reduced, as found in the renal cortex of diabetic rats (Palm et al., 2005). On the other hand, increased eNOS expression in eNOS transgenic mice results in increased production of $\mathrm{NO}$ as demonstrated in the aorta (Yamashita et al., 2000). Therefore, although the $\mathrm{Cx}$ changes in diabetes are similar to those observed in eNOS transgenic mice, the effect cannot be simply attributed to increased production of endothelial NO. In spite of these differences, changes to one of the downstream effectors of NO appear to be similar in diabetic and eNOS transgenic animals. Thus, although cGMP levels were increased in eNOS transgenic mice, NO-induced vasorelaxation was reduced due to decreased activity of both guanylate cyclase and protein kinase G (Yamashita et al., 2000). A similar decrease in NO-induced vasorelaxation has been reported in aorta of streptozotocin-induced diabetic rats due to decrease in guanylate cyclase and protein kinase G-protein (Zanetti et al., 2005). Interestingly, the activity of guanylate cyclase was increased in eNOS knockout mice (Brandes et al., 2000). Further experimentation is therefore necessary to clarify the involvement of guanylate cyclase and ROS in the mechanism by which elevated eNOS protein can alter $\mathrm{Cx}$ expression.

Together, our data demonstrate that an increase in eNOS protein can produce significant changes in expression of Cxs40 and 43 in afferent and efferent arterioles. These changes mimic those occurring in diabetes, during which eNOS protein is similarly increased in these arterioles. The regulation by eNOS of vascular Cx expression differs between the afferent and efferent arterioles in relation to both the cell type and $\mathrm{Cx}$ subtype involved, providing further evidence of the appreciable differences in structure and function of these two renal vessels.

\section{ACKNOWLEDGMENTS}

The authors thank Dr. Klaus Matthaei for designing the primers for eNOS transgenic genotyping and Mrs. Kate Meaney for assistance with the quantification of the immunohistochemical data.

\section{LITERATURE CITED}

Asaba K, Tojo A, Onozato ML, Goto A, Quinn MT, Fujita T, Wilcox CS. 2005. Effects of NADPH oxidase inhibitor in diabetic nephropathy. Kidney Int 67:1890-1898.

Bankir L, Bouby N, Trinh-Trang-Tan MM. 1987. Heterogeneity of nephron anatomy. Kidney Int 20(Suppl):S25-S39.

Bevers LM, Braam B, Post JA, van Zonneveld AJ, Rabelink TJ, Koomans HA, Verhaar MC, Joles JA. 2006. Tetrahydrobiopterin, but not L-arginine, decreases NO synthase uncoupling in cells expressing high levels of endothelial NO synthase. Hypertension 47:87-94.

Brandes RP, Kim D, Schmitz-Winnenthal FH, Amidi M, Godecke A, Mulsch A, Busse R. 2000. Increased nitrovasodilator sensitivity in endothelial nitric oxide synthase knockout mice: role of soluble guanylyl cyclase. Hypertension 35:231-236.

Carmines PK, Navar LG. 1989. Disparate effects of Ca channel blockade on afferent and efferent arteriolar responses to ANG II. Am J Physiol 256:F1015-F1020.

Carmines PK, Fujiwara K. 2002. Altered electromechanical coupling in the renal microvasculature during the early stage of diabetes mellitus. Clin Exp Pharmacol Physiol 29:143-148.

Christ GJ, Spray DC, el-Sabban M, Moore LK, Brink PR. 1996. Gap junctions in vascular tissues: evaluating the role of intercellular communication in the modulation of vasomotor tone. Circ Res 79: 631-646.

Denton KM, Luff SE, Shweta A, Anderson WP. 2004. Differential neural control of glomerular ultrafiltration. Clin Exp Pharmacol Physiol 31:380-386.

Evan AP, Dail WG Jr. 1977. Efferent arterioles in the cortex of the rat kidney. Anat Rec 187:135-145.

Gattone VH II, Luft FC, Evan AP. 1984. Renal afferent and efferent arterioles of the rabbit. Am J Physiol 247:F219-F228.

Hansen PB, Jensen BL, Andreasen D, Skott O. 2001. Differential expression of T- and L-type voltage-dependent calcium channels in renal resistance vessels. Circ Res 89:630-638.

Harats D, Kurihara H, Belloni P, Oakley H, Ziober A, Ackley D, Cain G, Kurihara Y, Lawn R, Sigal E. 1995. Targeting gene expression to the vascular wall in transgenic mice using the murine preproendothelin-1 promoter. J Clin Invest 95:1335-1344.

Harris AL. 2001. Emerging issues of connexin channels: biophysics fills the gap. Q Rev Biophys 34:325-472.

Harrison-Bernard LM, Monjure CJ, Bivona BJ. 2006. Efferent arterioles exclusively express the subtype $1 \mathrm{~A}$ angiotensin receptor: functional insights from genetic mouse models. Am J Physiol 290: F1177-F1186.

Hill CE, Phillips JK, Sandow SL. 2001. Heterogeneous control of blood flow amongst different vascular beds. Med Res Rev 21:1-60.

Hill CE, Rummery N, Hickey H, Sandow SL. 2002. Heterogeneity in the distribution of vascular gap junctions and connexins: implications for function. Clin Exp Pharmacol Physiol 29:620-625.

Hoffmann A, Gloe T, Pohl U, Zahler S. 2003. Nitric oxide enhances de novo formation of endothelial gap junctions. Cardiovasc Res 60: 421-430.

Huang PL, Huang Z, Mashimo H, Bloch KD, Moskowitz MA, Bevan JA, Fishman MC. 1995. Hypertension in mice lacking the gene for endothelial nitric oxide synthase. Nature 377:239-242.

Kawashima S, Yamashita T, Ozaki M, Ohashi Y, Azumi H, Inoue N, Hirata K, Hayashi Y, Itoh H, Yokoyama M. 2001. Endothelial NO synthase overexpression inhibits lesion formation in mouse model of vascular remodeling. Arterioscler Thromb Vasc Biol 21:201207.

Kuroki T, Inoguchi T, Umeda F, Ueda F, Nawata H. 1998. High glucose induces alteration of gap junction permeability and phosphorylation of connexin- 43 in cultured aortic smooth muscle cells. Diabetes 47:931-936.

Loutzenhiser K, Loutzenhiser R. 2000. Angiotensin II-induced $\mathrm{Ca}(2+)$ influx in renal afferent and efferent arterioles: differing roles of voltage-gated and store-operated $\mathrm{Ca}(2+)$ entry. Circ Res 87:551557.

Ohashi Y, Kawashima S, Hirata K, Yamashita T, Ishida T, Inoue N, Sakoda T, Kurihara H, Yazaki Y, Yokoyama M. 1998. Hypotension and reduced nitric oxide-elicited vasorelaxation in transgenic mice overexpressing endothelial nitric oxide synthase. J Clin Invest 102: 2061-2071.

Ozaki M, Kawashima S, Hirase T, Yamashita T, Namiki M, Inoue N, Hirata Ki K, Yokoyama M. 2002. Overexpression of endothelial nitric oxide synthase in endothelial cells is protective against ischemia-reperfusion injury in mouse skeletal muscle. Am J Pathol 160: $1335-1344$.

Paik SG, Fleischer N, Shin SI. 1980. Insulin-dependent diabetes mellitus induced by subdiabetogenic doses of streptozotocin: oblig- 
atory role of cell-mediated autoimmune processes. Proc Natl Acad Sci USA 77:6129-6133.

Palm F, Buerk DG, Carlsson PO, Hansell P, Liss P. 2005. Reduced nitric oxide concentration in the renal cortex of streptozotocininduced diabetic rats: effects on renal oxygenation and microcirculation. Diabetes 54:3282-3287.

Prabhakar SS. 2004. Role of nitric oxide in diabetic nephropathy. Semin Nephrol 24:333-344.

Roh CR, Heo JH, Yang SH, Bae DS. 2002. Regulation of connexin 43 by nitric oxide in primary uterine myocytes from term pregnant women. Am J Obstet Gynecol 187:434-440.

Rummery NM, Hickey H, McGurk G, Hill CE. 2002. Connexin37 is the major connexin expressed in the media of caudal artery. Arterioscler Thromb Vasc Biol 22:1427-1432.

Rummery NM, Grayson TH, Hill CE. 2005. Angiotensin-converting enzyme inhibition restores endothelial but not medial connexin expression in hypertensive rats. J Hypertens 23:317-328.

Sato T, Haimovici R, Kao R, Li AF, Roy S. 2002. Downregulation of connexin 43 expression by high glucose reduces gap junction activity in microvascular endothelial cells. Diabetes 51:1565-1571.

Satoh M, Fujimoto S, Haruna Y, Arakawa S, Horike H, Komai N, Sasaki T, Tsujioka K, Makino H, Kashihara N. 2005. NAD(P)H oxidase and uncoupled nitric oxide synthase are major sources of glomerular superoxide in rats with experimental diabetic nephropathy. Am J Physiol 288:F1144-F1152.

Schalkwijk CG, Stehouwer CD. 2005. Vascular complications in diabetes mellitus: the role of endothelial dysfunction. Clin Sci (Lond) 109:143-159.

Segal SS. 2005. Regulation of blood flow in the microcirculation. Microcirculation 12:33-45.

Shiraishi M, Wang X, Walsh MP, Kargacin G, Loutzenhiser K, Loutzenhiser R. 2003. Myosin heavy chain expression in renal afferent and efferent arterioles: relationship to contractile kinetics and function. FASEB J 17:2284-2286.
Sladek SM, Westerhausen-Larson A, Roberts JM. 1999. Endogenous nitric oxide suppresses rat myometrial connexin 43 gap junction protein expression during pregnancy. Biol Reprod 61:8-13.

Szkudelski T. 2001. The mechanism of alloxan and streptozotocin action in B cells of the rat pancreas. Physiol Res 50:537546.

Turoni CM, Reynoso HA, Maranon RO, Coviello A, Peral de Bruno M. 2005. Structural changes in the renal vasculature in streptozotocin-induced diabetic rats without hypertension. Nephron Physiol 99:50-57.

Yamashita T, Kawashima S, Ohashi Y, Ozaki M, Rikitake Y, Inoue N, Hirata K, Akita H, Yokoyama M. 2000. Mechanisms of reduced nitric oxide/cGMP-mediated vasorelaxation in transgenic mice overexpressing endothelial nitric oxide synthase. Hypertension 36:97102.

Yao J, Hiramatsu N, Zhu Y, Morioka T, Takeda M, Oite T, Kitamura M. 2005. Nitric oxide-mediated regulation of connexin 43 expression and gap junctional intercellular communication in mesangial cells. J Am Soc Nephrol 16:58-67.

Yuan BH, Robinette JB, Conger JD. 1990. Effect of angiotensin II and norepinephrine on isolated rat afferent and efferent arterioles. Am J Physiol 258:F741-F750.

Zaki FG, Keim GR, Takii Y, Inagami T. 1982. Hyperplasia of juxtaglomerular cells and renin localization in kidney of normotensive animals given captopril: electron microscopic and immunohistochemical studies. Ann Clin Lab Sci 12:200-215.

Zanetti M, Barazzoni R, Stebel M, Roder E, Biolo G, Baralle FE, Cattin L, Guarnieri G. 2005. Dysregulation of the endothelial nitric oxide synthase-soluble guanylate cyclase pathway is normalized by insulin in the aorta of diabetic rat. Atherosclerosis 181: 69-73.

Zhang J, Hill CE. 2005. Differential connexin expression in preglomerular and postglomerular vasculature: accentuation during diabetes. Kidney Int 68:1171-1185. 